Original Contribution

\title{
EFFECT OF CADMIUM ON SEED GERMINATION AND EARLIER BASIL (OCIMUM BASILICUM L. AND OCIMUM BASILICUM VAR. PURPURESCENS) SEEDLING GROWTH
}

\author{
A. Gharebaghi ${ }^{1 *}$, M. H. Alborzi Haghighi ${ }^{2}$ H. Arouiee ${ }^{1}$ \\ ${ }^{1}$ Department of Horticultural Sciences, Ferdowsi University of Mashhad, Mashhad, Iran \\ ${ }^{2}$ Department of Water Engineering, Agricultural School, Shiraz University, Iran
}

\begin{abstract}
As one of the consequences of heavy metal pollution in soil, water and air, plants are contaminated by heavy metals. Thus, this work aims to evaluate the response of two basil species (Ocimum basilicum L. and Ocimum basilicum var. Purpurescens) to treatment with cadmium (heavy metal) in the roots and leaves of young plants. This experiment was conducted on the basis of a completely randomized design (CRD) in greenhouse condition with four doses $(0,5,10,20 \mathrm{mg} / \mathrm{lit})$ of cadmium heavy metal. The results indicated that germination of seeds was inhibited by cadmium as compared to control. In addition number of leaves, plant height, plant height above cotyledon leaves and root length were clearly shortened when the concentration of cadmium exceeded. Generally, it was shown that $\mathrm{Cd}$ is more toxic for Ocimum basilicum var. Purpurescens than Ocimum basilicum L.
\end{abstract}

Key words: Basil, Cadmium, Germination, Toxicity

\section{INTRODUCTION}

During the last decades the contamination of soil became very extensive and dangerous problem as a consequence of industrial activities (metallurgy, chemistry, energetics, etc.) (1). All these heavy metals: $\mathrm{Cd}, \mathrm{Cu}, \mathrm{Hg}, \mathrm{Ni}, \mathrm{Pb}$ and $\mathrm{Zn}$ are the most dangerous (2). There are two aspects on the interaction of plants with heavy metals: (i) heavy metals show negative effects on plants, and (ii) plants have their own resistance mechanisms against toxic effects and for detoxifying heavy metal pollution (3). Heavy metal accumulation in soils is of concern in agricultural production due to its adverse effects on food quality, crop growth, and environmental health (4). These metals are mostly absorbed by plants easily and prove toxic to plants that can be observed as growth retardation as a result of alterations in biochemical process like inhibition of enzyme activity, protein penetration and impaired nutrition etc. (5). Cadmium (Cd), being a highly toxic metal pollutant of soils, inhibits root and shoot

\footnotetext{
*Correspondence to: A. Gharebaghi, Department of horticultural sciences, college of Agriculture, Mashhad University. Mashhad. Iran, Email:abozargharebaghi65@gmail.com
}

growth and yield production, affects nutrient uptake and homeostasis, and is frequently accumulated by agriculturally important crops and then enters the food chain with a significant potential to impair animal and human health (6). Aydinalp and Marinoya (7) expressed the dose of 5 ppm of $\mathrm{Cr}^{+6}, \mathrm{Cu}^{+2}, \mathrm{Ni}^{+2}$, and $\mathrm{Zn}^{+2}$ increased the shoot size by $13.0 \%, 59.0 \%$, $35.0 \%$, and $6.6 \%$, respectively). Basil is used as a medicinal herb in medical treatments such as for headaches, coughs, diarrhea, worms, and kidney malfunctions. Basil essential oil has been utilized extensively in the food industry as a flavoring agent, and in perfumery and medical industries (8). The flowers and leaves of the plant constitute a rich source of essential oils (9). An infusion of the leaves is used as a disinfectant and as an insecticide (9). Present study is done to examine the toxicity of cadmium on germination and seedling growth of Ocimum basilicum L., and Ocimum basilicum var. Purpurescens at varying concentrations.

\section{MATERIALS AND METHODS}

Basil seeds Ocimum basilicum L. and Ocimum basilicum var. Purpurescens were immersed in $3 \% \quad \mathrm{v} / \mathrm{v}$ 
formaldehyde/deionized water for five minutes to avoid fungal contamination. After that, the seeds were washed with deionized water and placed in pot which filled with soil pots irrigated with the heavy metals of $\mathrm{Cd}^{+2},\left[\mathrm{CdSO}_{4} .8 \mathrm{H}_{2} \mathrm{O}\right]$ were used at the concentrations of $0,5,10,15$, 20 ppm. Each treatment was replicated three times for statistical purposes. Pots were maintained in greenhouse at 20-30 ${ }^{\circ} \mathrm{C}$ and natural light. The seedlings were harvested after two weeks and the aboveground plant, number of leaves, plant height, plant height of cotyledon leaves and root length were recorded.

The data were analyzed by analysis of variance (ANOVA) to determine the effect of treatments, Treatment means were compared using LSD at the 5\% level of probability.

GHAREBAGHI A., et al.

\section{RESULTS AND DISCUSSION}

The effects of the different concentrations of $\mathrm{Cd}$ on aboveground plant of 2 cultivar of basil were presented in (Figure 1). There was a reduction in aboveground plant as metal concentrations in the growing media. The results of the present study revealed that $\mathrm{Cd}$ adversely influenced the seed germination. When the concentration of metals exceeded certain levels, an abnormal germination was resulted. $\mathrm{Cd}$ significantly decreased plant height of cotyledon leaves and plant height more than controls then the longest plant height and plant height of cotyledon leaves occurred in control plants (Figures 2, 3). Claire et al. (10) obtained similar results in a study using nickel and other heavy metals on cabbage, lettuce, millet, radish, turnip, and wheat.

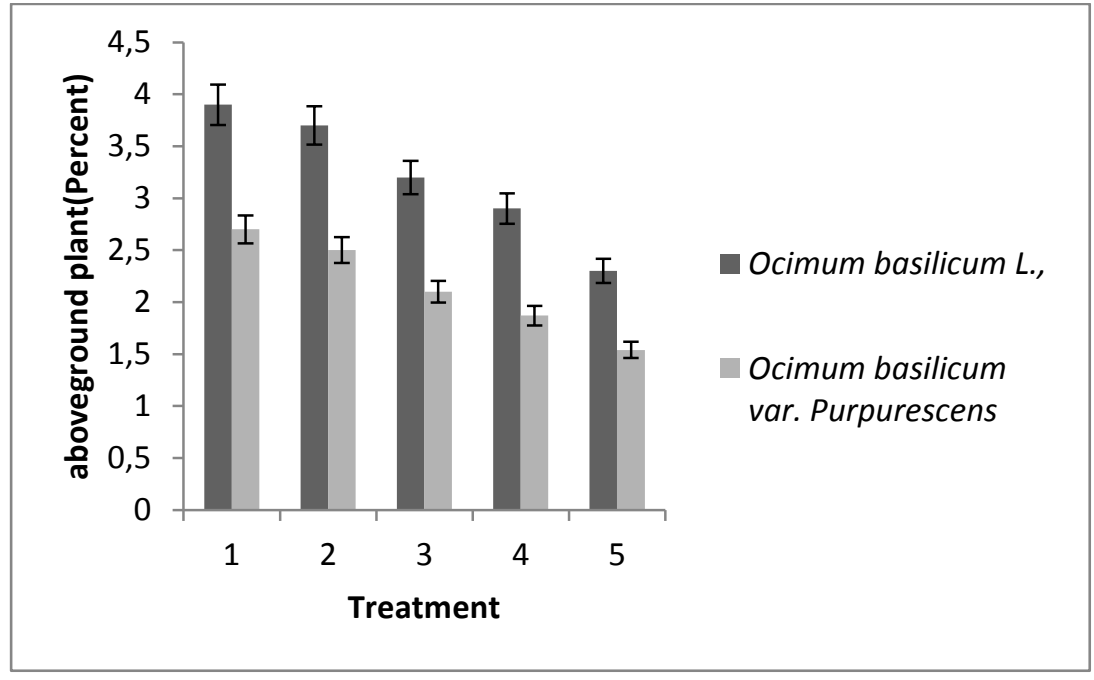

Figure 1. The effect of varying concentrations of cadmium on aboveground plant of Ocimum basilicum L., and Ocimum basilicum var. Purpurescens.

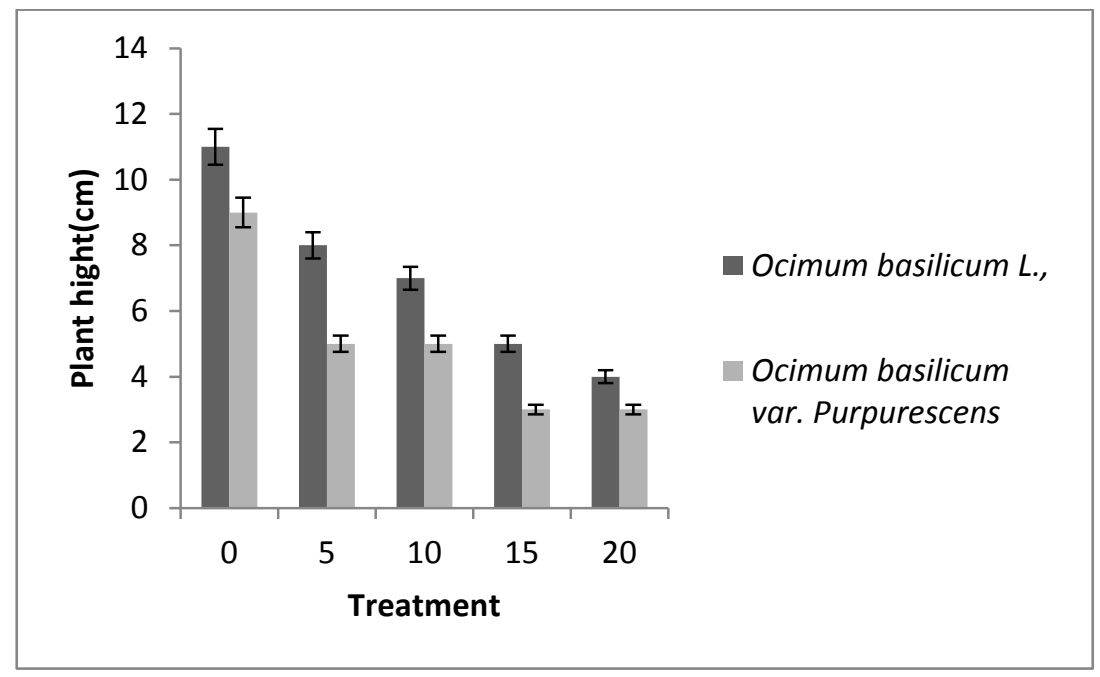

Figure 2. The effect of varying concentrations of cadmium on plant height of Ocimum basilicum L., and Ocimum basilicum var. Purpurescens. 


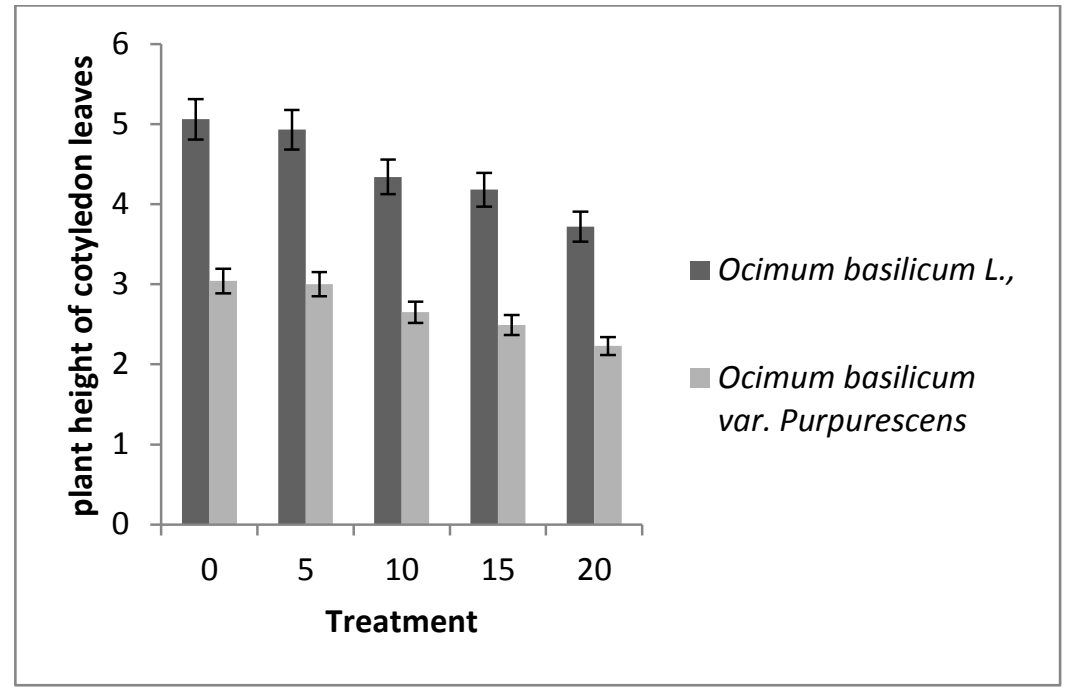

Figure 3. The effect of varying concentrations of cadmium on plant height of cotyledon leaves Of Ocimum basilicum L., and Ocimum basilicum var. Purpurescens.

Chugh and Sawhney (11) reported that seed germination of pea (Pisum sativum L.) was affected by up to $0.5 \mathrm{mM}$ of $\mathrm{Cd}$ doses. The root growth was presented in Figure 4. $\mathrm{Cd}$ decreased the root growth by increasing the concentration respectively, as compared to the root growth of the control plants. No significant difference in roots length between control and $\mathrm{Cd} 5 \mathrm{ppm}$. The inhibition of root growth can be attributed in part to the inhibition of mitosis, the reduced synthesis of cell-wall components, damage to the golgi apparatus and changes in the polysaccharide metabolism, while browning is caused by suberin deposits (12). Presented data in Figure 5 shows that different cobalt levels decreased number of leaves in two basil seedlings.

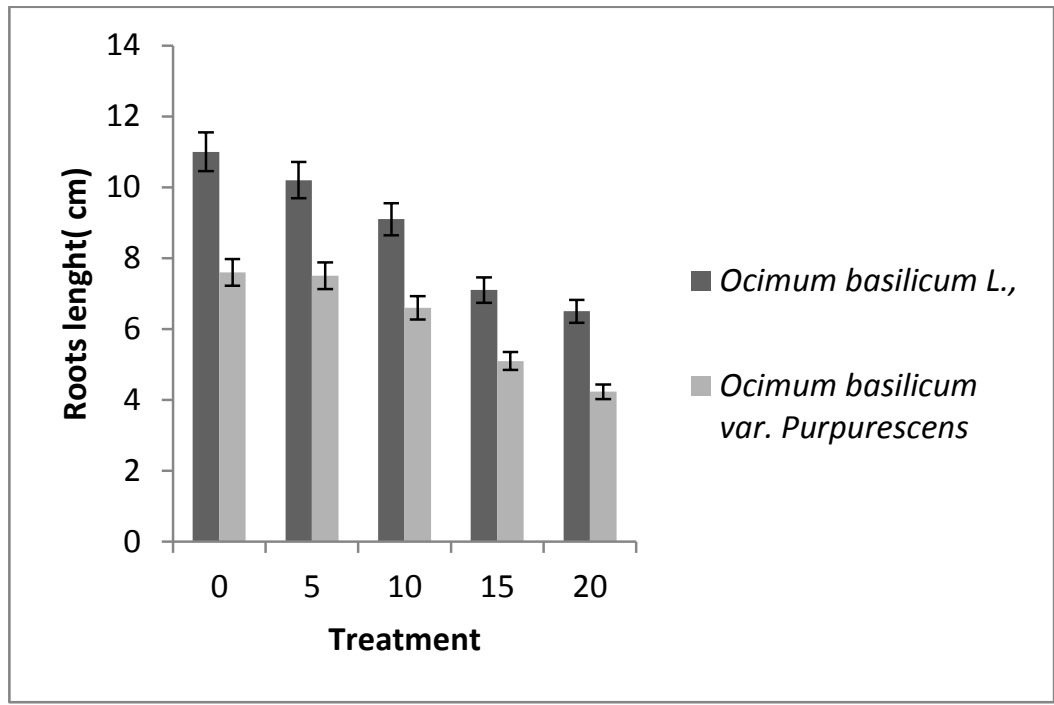

Figure 4. The effect of varying concentrations of cadmium on roots length of Ocimum basilicum L., and Ocimum basilicum var. Purpurescens.

\section{CONCLUSIONS}

According to the results, the seed germination and earlier seedling growth of the basil plant is seriously affected by $20 \mathrm{ppm}$ of Cd. This heavy metal is more toxic for Ocimum basilicum var. Purpurescens than Ocimum basilicum L. in aboveground plant, number of leaves, plant height, plant height of cotyledon leaves and roots length. Detailed studies need to be done in order to establish the maximum amount of $\mathrm{Cd}$ that the plants may tolerate, and the ability of the basil plants to germinate and grow in media containing mixtures of other heavy metals. 


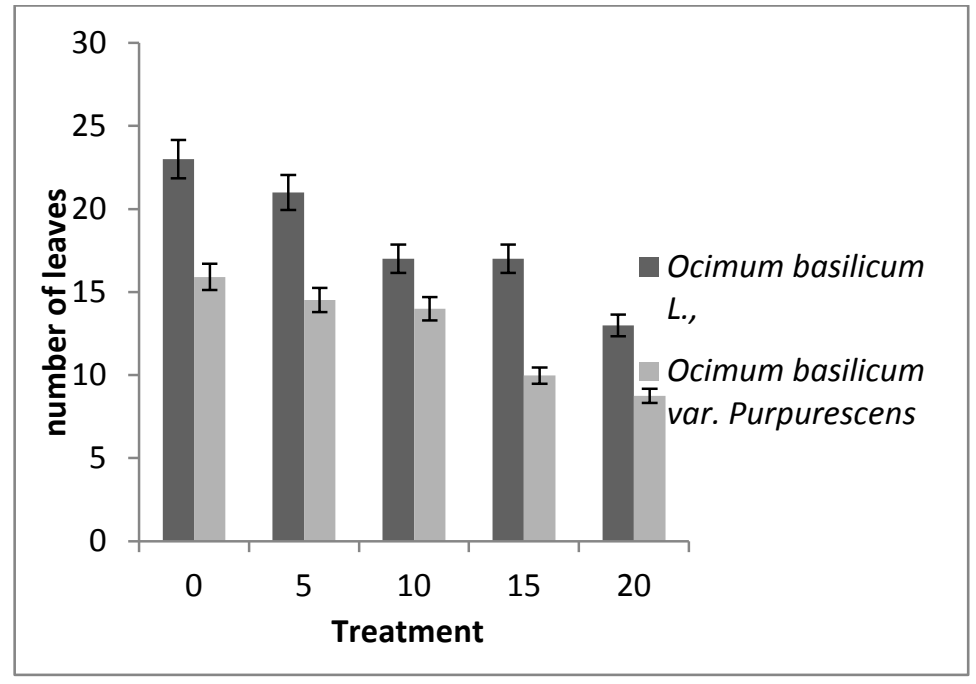

Figure 5. The effect of varying concentrations of cadmium on number of leaves of Ocimum basilicum L., and Ocimum basilicum var. Purpurescens.

\section{REFERENCES}

1. Hocking, P.J., McLaughlin, M. J. Genotypic variation in cadmium accumulation by seed of linseed and comparison with seeds of some other crop species. Aust. J. Agric. Res, 51: 427-433, 2000.

2. Wagner, G.J. Accumulation of cadmium in crop plants and its consequences to human health. Adv. Agron, 51: 173-212, 1993.

3. Chatterjee, J., Chatterjee, C. Phyto-toxicity of Cobalt, Chromium, and Copper in Cauliflower. Environmental Pollution, 109: 69-74, 2000.

4. Islam, E. U., Yang, X. E., He, Z. L., Mahmood, Q. Assessing potential dietary toxicity of heavy metals in selected vegetables and food crops. J. Zhejiang University Science, 8: 1-13, 2007.

5. Arun, K.S., Cervantes, C., Loza-Tavera, H., Avudainayagam, S. Chromium toxicity in plants. Environ. Int, 31: 739-753, 2005.

6. Di Toppi, S.L., Gabrielli, R. Response to cadmium in higher plants. Environ. Exp. Bot, 41: 105-130, 1999.

7. Aydinalp, C., Marinova, S. The effects of heavy metals on the seed germination and plant growth on alfalfa plant (Medicago Sativa). Bulgarian .J. Agri. Sci., 15: 347350, 2009.

8. Simon, J.E., Quinn, J., Murray, R.G. Basil: a source of essential oils. In: Janick, J., Simon, J.E. (Eds.), Advanced in New Crops. Timber Press, Portland, OR, pp. 484-489, 1999.
9. Silva, M.G.V., Craveiro, A.A., Matos, F.J.A., Machado, M.I.L., Alencar, J.W. Chemical variation during daytime of constituents of the essential oil of Ocimum gratissimum leaves. Fitoterapia, 70: 32-34, 1999.

10.Claire, L. C., Adriano, D. C., Sajwan, K. S., Abel, S. L., Thoma, D. P., Driver J. T. Effects of Selected Trace Metals on Germinating Seeds of Six Plant Species. Water Air and Soil Pollution, 59: 231-240, 1991.

11.Chugh, L. X., Sawhney, S.K. Effect of Cd on seed germination. Amylase and rate of respiration of germinating pea seeds. Environ. Poll, 92: 1-5, 1996.

12.Punz, W.F., Sieghardt, H. The response of roots of herbaceous plant species to heavy metals. Environ. Exp. Bot. 33: 85-98, 1993.

13. Michalak, A. Phenolic compounds and their antioxidant activity in plants growing under heavy metal stress. Polish J. Environ. Studies, 15: 523-530. 2006.

14.Zheljazkov, V. D., Craker, L. E., Xing, B. Effects of $\mathrm{Cd}, \mathrm{Pb}$, and $\mathrm{Cu}$ on growth and essential oil contents in dill, peppermint, and basil. Environmental and Experimental Botany, 58: 9-16, 2006.

15.Zheljazkov, V. D., Craker, L. E., Xing, B., Nielsen, N. E., Wilcox, A. Aromatic plant production on metal contaminated soils. The Science of the Total Environment, 395:51-62, 2008. 